\title{
MEDIATION ROLE OF ABSORPTION CAPACITY ON THE RELATIONSHIP BETWEEN RELATIONAL NETWORK AND THE ENTREPRENEURIAL ORIENTATION OF TUNISIAN CONTRACTORS
}

\author{
Ghodbane Adel ${ }^{1}$ \\ Affes Habib ${ }^{2}$
}

\begin{abstract}
The objective of this paper is to analyze the mediating effects of the absorption capacity between relational network of contractors and their entrepreneurial orientation in the specific case of Tunisian SMEs. The originality of this approach lies in the development of the concept of absorption capacity for SMEs which lack the means to profit from their own relational fabrics in terms of identification and exploitation of opportunities business.
\end{abstract}

Keywords: Absorption capacity, knowledge, entrepreneurial orientation, relational network, Tunisia.

\section{JEL Classification:L26}

\section{Introduction}

Today, SMEs operate in an environment marked by increased competitive intensity and a hardening global competition. Indeed, SMEs are constrained in terms of price, quality, quantities and time. Moreover, competitive strategies refer to major decisions taken by contractors to ensure the sustainability of their businesses. These decisions are a response to an environment marked by unpredictability, threat and hyper-competition.

In this context, the company must deploy strategies and resources to meet the new challenges posed by this new competitive environment and stand out from its rivals thanks to a competitive advantage (Venkataraman \& Prescott, 1990; Chorn, 1991; Nath \& Suharshan, 1994).

In fact, the concept of entrepreneurial orientation (EO) emerged following the work of D. Miller, (1983) on which this author postulates that in the simple organization (according to the concept advocated by Mintzberg, 1973) is the personality of the leader and leadership that matter; For this purpose, unlike the planner organization in which the company's performance is enhanced by planning, in the organic organization, what counts is the adaptation of the business and its adjustment to the specific features of environment. Moreover, in order to assess the entrepreneurial intensity, D. Miller, founded a proxy integrating innovation, pro-activity, and the propensity to take risks. Therefore, the EO is treated as an organizational phenomenon that incorporates planning, analysis, decision making and other aspects of organizational culture (Hart, 1992 ;Lumpkin \& Dess, 1996). Based on these ideas, EO refers to various policies and practices that are embodied by strategic decisions and entrepreneurial actions. In addition, it is treated as a process of formulating business strategies in which policy makers can modify the organization and see the future of their businesses.

In this regard, entrepreneurship is a process that allows companies to earn economic rents by identifying opportunities, evaluate and select those with the greatest potential, and then put up the operating strategies for marketing and maximizing value (Oviatt \& McDougall, 2005; Shane \& Venkataraman, 2000). Companies that focus on this process as part of their corporate strategies, tend to be more related to innovation, pro-activity and risk taking, comparing to those who did not (Lumpkin \& Dess, 1996; Miller, 1983; Wiklund, 1999; Zahra \& Covin, 1995). These three dimensions have also been processed by Danny Miller (1983). This author defined the EO through these three dimensions, namely innovation, risk taking and pro-activity.

\footnotetext{
${ }^{1}$ Faculty of Economics and Management, University of Sfax, Tunisia adelghodbane@gmail.com

${ }^{2}$ Faculty of Economics and Management, University of Sfax, Tunisia habib.affes@yahoo.fr
} 
For their part (Covin \& Slevin, (1989); Voss and al., (2008)) have defined entrepreneurial orientation as a strategic posture, a nested organizational philosophy that facilitates decision taken specific to the organization. Therefore, the EO is not synonymous with entrepreneurship, but rather to articulate the perspective of the strategic choices leading to an entrepreneurial trend, in accordance with the definition of Lumpkin \& Dess, (1996:136).

Moreover, given the lack of resources to pursue their entrepreneurial orientation, SMEs are required, actually more than other time, to benefit from their relational networks thanks to a sufficient absorption capacity. Therefore, the objective of this paper is to analyze the mediating effects of the absorption capacity between relational network of contractors and their entrepreneurial orientation in the specific case of Tunisian SMEs.

\section{Absorption capacity and entrepreneurial orientation}

Todorova \& Durisin, (2007) have examined and refined the concept of absorption capacity of Zahra and George (2002). They had also re-conceptualized the model proposed by Cohen \& Levinthal (1990). From their side, Mahroum and al., (2008) have inserted the absorption capacity in their innovation model. More recently, Julien and al., (2009) had applied the model of Zahra \& George (2002) in a context of Congolese small businesses while identifying the various informational sources. To build on the knowledge gained from the outside, these later must be relayed by individuals within their functional area, and between different services (e.g. between R \& $\mathrm{D}$ and production). This is the "realized absorptive capacities" within the meaning of Zahra \& George, (2002) which are assimilated as "inward looking absorptive capacities". In this regard, absorption capacity is essential for processing and operation phases, and allows the commercial exploitation of knowledge. Once knowledge has been acquired outside, by people, qualified as "gatekeepers who stand at the interface of the firm and the external environment" (Cohen and Levinthal, 1990:133), they must be disseminated as widely as possible within the company. This is to build the absorption capacity at a service in which individuals possess similar technical knowledge. Then, this absorption capacity will be targeted to all the organization, where individuals have very diverse backgrounds, including through the "boundary spanning" (Cohen and Levinthal, 199:133). To allow a good flow of knowledge within the company, it is necessary that individuals possess knowledge and common modes of reasoning ${ }^{1}$. Individuals who communicate must share either the same scientific discipline or the same type of practical know-how, and often also have a vision of common goals. For example, a researcher and a mechanical engineer may communicate on the development and the industrialization of a new type of engine developed by the R \& $\mathrm{D}^{2}$. This case is all the easier for both parties since they master the same field of expertise and therefore, they have the same vocabulary and a common understanding of problems to solve. If there is no redundancy ${ }^{3}$, no communication is possible.

\subsection{Absorption capacity and pro-activity}

The absorption capacity enhances the existing knowledge base of the company and encourages new knowledge creation activities, which in turn influence entrepreneurial success (Bojica \& Fuentes Fuentes, 2011). In addition, the absorption capacity allows the exploitation and the integration of external knowledge, increasing the likelihood of reaching a better understanding of entrepreneurial companies (Zahra et al., 1999).

The capacity of absorption represents a form of learning that involves the pursuit of knowledge that does not exist in the organization in order to enrich the current value, starting with the internal management of this new knowledge by the organization. On the other hand,

\footnotetext{
${ }^{1}$ That is to say, an overlap in their respective areas of expertise.

${ }^{2}$ Through the knowledge acquired from universities or collaborators.

${ }^{3}$ For example, each individual control an area of expertise totally different from those of others.
} 
the exploitation involves being able to transform existing knowledge to an added value created by the organization to its current customers (Prieto, 2010).

Absorptive capacity affects competitive advantage through the development of new products, processes, systems and forms of organization, activities related to corporate entrepreneurship. The continuous pursuit and the exploitation of new business opportunities of entrepreneurial companies (Hayton \& Kelley, 2006) require injection of resources and new knowledge in business operations from several external sources (Zahra et al., 2009). Therefore, companies that develop their absorption capacities and knowledge exploitation through the use of different external sources (e.g. alliances) can boost the results of their entrepreneurial activities (Bojica \& Fuentes Fuentes, 2011).

The ability to acquire knowledge is important, but the company must also be able to integrate and use the knowledge gained to his advantage. The need to integrate and use knowledge focuses on the absorption capacity of the enterprise. The literature of entrepreneurship is filled with examples of the role of capabilities related to learning in business performance. For example, Hurley and Hult, (1998) have showed that market orientation and learning orientation are associated with the company's ability to innovate in order to achieve favorable results. In addition, Hult, Nichols, Giunipero, and Hurley, (2000) find that organizational learning improves relationships in the supply chain. Organizational learning is a dynamic process of creation, acquisition and integration of knowledge necessary to the development of resources and capabilities that improve organizational performance (Lopez, Peon and Ordas, 2005). Previous studies (e.g., Dale, 1994; Nevis et al., 1995) have highlighted the place of organizational learning which can be identified as a complex process integrating knowledge acquisition, dissemination and shared implementation (interpretation). Therefore, this process facilitates the exploitation of knowledge, distribution, application and transformation of this knowledge to resources for the organization, and thus, serving as a database, procedures and systems important for the expansion of the business. Hence, one can formulate the following Central hypothesis.

\section{H.1: The absorption capacity affects directly and indirectly the pro-activity of the contractor.}

\subsection{Absorption capacity and innovation}

The absorption capacity is defined as a set of organizational routines by which firms acquire, assimilate, transform and exploit knowledge to produce a dynamic organizational capability (Zahra \& George, 2002). Knowledge acquisition is the ability to recognize, value, and acquire external knowledge which is essential for a company's operations (Lane \& Lubatkin, 1998 ; Zahra \& George, 2002).

The acquisition, assimilation, transformation and exploitation of knowledge are important for organizational innovation. The absorption capacity appears to be one of the most important determinants of a company's ability to acquire, assimilate, and to use new knowledge in order to enhance its performance of innovation. Companies need to increase their absorption capacity to acquire, assimilate, transform and exploit knowledge that can lead to organizational innovations (Daghfous, 2004). Therefore, businesses absorption capacity can affect the efficiency of innovation activities (Cockburn \& Henderson, 1998). In addition, the absorption capacity enables businesses to acquire and use external and internal knowledge which affect their innovation capabilities (Daghfous, 2004).

The absorption capacity is the capacity to acquire, assimilate, transform and exploit knowledge that can determine its levels of organizational innovation and competence (Cohen \& Levinthal, 1990; Daghfous, 2004 ; Vinding , 2006). In this regard, Cohen \& Levinthal, (1990) ; Daghfous, (2004) emphasized that the absorption capacity of a company is beneficial for organizational learning and R \& D activities. From his side, Schilling, (1998) stated that with the absorption ability, companies expand their knowledge base and skills to improve their ability to 
assimilate, to use future information and thus, the possibly improve of technological developments. Therefore, when companies have a higher absorption capacity, it would increase their innovation performance (B.H. Tarek \& A. Sami, 2014). Therefore, in this study we consider that innovation activity that relies on the creation and sharing of information tends to pool knowledge in space. The sharing of tacit knowledge, usually transmitted by direct contact, makes this point vividly. Moreover, the proximity, the prior knowledge (Shane, 2000), the trust and the sharing of information help to transform information into knowledge. For the entrepreneur, relational network (Aldrich \& Zimmer, 1986; Julien \& al., 2004) and the absorption capacity of the organization (Cohen \& Levinthal, 1990 ; Zahra \& George, 2002) help to transform information into knowledge. The latter, in turn stimulates innovation and identification of business opportunities, and facilitates appropriate decision-making (Vaghely et al., 2007). In other words, the apprehension guides action, and it can also facilitates understanding of the information. For his part, Zeleny, (2005) showed that knowledge is synonymous with contextual, relevant and developed information. In addition, a more detailed distinction between the two concepts can be apprehended by postulating that "knowledge is an action and information is a description of the action."

Furthermore, many research (Daft \& Weick, 1984 ; Thomas et al., 1993) showed that firms can be considered as interpretation systems that analyze the environment and carry out a filtration of technologies to guide future action. From this point of view of demand, knowledge providers are considered static owners of relevant knowledge waiting to be discovered by active researchers in possession of sufficient absorption capacity. The studies focusing on networks suggest, however, that the knowledge providers are not that dumb, or knowledge dispersed easily recognizable and easily integrated. This is especially true in emerging technological environments where many companies lack of knowledge internally and established routines required for the absorption capacity (Bogner \& Barr, 2000) due to a lack of both past experience (Zollo \& Winter, 2002) and an appropriate business orientation to knowledge (Wiklund \& Shepherd, 2003). In what follow, we try to test the following hypothesis:

\section{H.2: The absorption capacity affects directly and indirectly the innovation of the contractor.}

\subsection{Absorption capacity and risk taking}

Innovation is not without risk. Innovation, as Schumpeter foresaw, is a destructive processes, new tools and methods, and it always includes that part of leap in the dark, synonymous with risk. It carries within it a feature that hinders its development: the concept of failure; we do not innovate without the risk that is to say before the action without accepting the failure and the discovery of unpredictable elements at one time, given the state of knowledge. These risks are mainly of two types: In one hand, the technical risk that is to say that the characteristics of the product or service may not comply with specifications, or simply the expected performance. The many delays in the marketing of "new" products come in large part of this deviation from the forecast. In the other hand, social or societal risk related to the reaction of the consumer, the customer or distribution channels, competition, the legislator, the most diverse lobbies which can inhibit the dissemination of new ideas.

To these reserves, or obstacles, have been added in recent years so more and more, the concept of a global risk that is to say the refusal to accept the error, trial and error or possible collateral damage.

Thus, innovation can provide greater opportunities for growth, but also, a higher risk (Danneels, 2002). In the same way, several studies have showed the idea that the diversity of sources of information affects the potential negative learning (Lane \& Lubatkin, 1998 ; Fleming \& Sorenson, 2001). In fact, this idea goes back to Cohen \& Levinthal (1990) who eagerly analyzed the concept of absorption capacity. For this purpose, these authors have demonstrated that the absorption capacity of a firm is positive depending on its level of prior knowledge. Moreover, Lubatkin \& Lane, (1998) highlighted the fact that the similarity of the 
sources of knowledge determines positively differences of absorption capacity of firms as a result of a greater capacity for learning different innovation partners. This issue has already been addressed in an individual perspective by psychologists, who proposed that the prior knowledge facilitates learning because treatment of knowledge is established by associative memory (Bower \& Hilgard, 1981; Lindsay \&Norman, 1977). In other words, the potential absorption capacity prevents companies to lock in a specific area of expertise and run the risk of not seeking alternative technologies by providing strategic flexibility to adapt in various contexts of industry.

If we follow conceptualizations of Zahra \& George (2002) ; Lane \& al. (2006) and apply them to the context of cross-industry innovation, we see that the notion of potential absorption capacity comprises the steps of recognition process, assimilation and retention of knowledge from other external industries to prepare the ground for future knowledge transfer. Hence, we can formulate the following hypothesis:

\section{H.3: The absorption capacity affects directly and indirectly the risk taking of the contractor.}

\section{Methodology and results}

Before presenting the results of the confirmatory analysis, we want to clarify the conditions for its implementation. The majority of variables cannot be considered normal or pseudo-normal. This is the reason that the use of Bootstrap procedure with 100 replications of the sampling and the method of Maximum Likelihood (ML) has been selected for the parameter estimates. We try in what follow to test the mediation of the variable related to the absorption capacity between relational network and entrepreneurial orientation. We expose below the necessary calculation steps in order to identify the mediating effect and the strength of this indirect effect will be tested through the complete model. The technique of structural equations, as recommended by Keny \& Baron, (1986) was used among all possibilities of analysis of causal effects. Several indices will be mobilized to assess the validity, quality and relevance of a measurement model. The use of confirmatory factor analysis with adjustment function (ML) is sensitive to the violation of the assumption of normality of the different multi-dimensional relational network.

However, we preferred to use a bootstrap procedure to ensure the validity of results. As for the validity of relations, two types of service must be assessed. Statistical significance is assessed through e "t-student" tests on correlations. The practical significance is assessed by the value of R-square. Given this wealth of information, the use of indices to compare the suitability of several models between them (NFI NNFI, CAIC, GFI, AGFI) and an index associated with a confidence interval (RMSEA). In consequence, we retain the indicators according to their availability in STATISTICA 5.1.

All data collected by a questionnaire were subjected to a number of statistical analyzes with the aim to discover, describe and understand the process of access to external resources. However, the information provided by the questionnaire was not all directly usable as is. They were submitted to a preparatory work to make them operational for statistical processing. Preparing data includes a number of steps which are intended to transmit the questionnaires variable file on which will be considered complete statistical processing. Two main phases can then be distinguished: the verification of questionnaire" and "codification of answers.

This systematic work has shown that the successful questionnaire is completed legibly. Only a very few cases involved minor anomalies. It was essentially a few unintentional oversights responses to an item, generating few missing values. Thus, there was no removal of relevant questionnaires.

The questions were articulated as follows: 
- First, questions related to innovation adopted by companies (including their industry, specialization in the IT sector, characteristics of the innovation model to follow, innovation typology and the minimum values of innovation);

- Then, questions on attitudes towards risk and related to the factors of assuming the risk necessary to the transition to the act of creation. In this regard, items were measured by measuring scale to 4 points;

- Finally, questions related to the pro-activity and which was focused on benefits to anticipate needs in terms of business creation.

After filtering, our sample consists of 140 Tunisian SMEs. To study the dimensionality of the entrepreneurial orientation, a first factor analysis with SPSS 17 software, the vari-max rotation method with Kaiser normalization were selected because of the various scales are not assumed to be independent. Before the analysis, we first checked whether the conditions for the factorization of the variables were observed. Measuring KMO is of the order of 0.617. This value is satisfactory for the exploratory phase. The statistical picture of the anticorrelation matrix is satisfactory. The Bartlett sphericity test is also significant to the threshold of 0.001 . This analysis has reduced the number of items from 34 to 28 (total outstanding items) which justify the use of a second factor analysis. Three factors were obtained and their interpretation is specified in the table 1 .

Table 1: Items and variables of entrepreneurial orientation

\begin{tabular}{|l|l|}
\hline \multicolumn{1}{|c|}{ Items } & Variables \\
\hline - Sector of company & \\
-Specialty In the IT sector & Innovation \\
- The Model to follow in the innovation system & \\
- Product type according to the degree of innovation & \\
-Conductor and project monitoring & \\
- The Minimum values of innovation & \\
\hline - Risks towards the economic environment & Attitude towards risks \\
- Risk towards the relational and family members & \\
-Risk towards institutions & \\
-Risk towards funding & \\
-Risk towards the competence and training skills & \\
- Lack of customer responsiveness towards the product & \\
- Lack of flexibility and insufficiency of regulations & \\
-Lack of market information & \\
-Lack of information on technology & \\
-Lack of qualified people & \\
- Organizational rigidities within the enterprise & \\
-Lack of appropriate funding sources & \\
- High cost of innovation & \\
- Excessive perceived economic risks & \\
\hline -Fort need for independence & \\
-Search Job & \\
- The need for recognition & \\
-The taste of defiance & \\
- The Need for self-esteem & \\
-Search of power & \\
\hline
\end{tabular}


The first factor related to innovation is interested in different types of organizational innovation (product, process, and marketing) that can be implemented to develop the new production methods, a new idea, and thus, to give a dynamic entrepreneurial and latent capacity in both forms: technological form and behavioral form. From 6 items we have valued innovative capacity of the contractor based mainly on the exploitation of his innovative skills and his experiences with the product and technology used and therefore, to have a good knowledge of markets, technologies or industry. The second factor which is related to attitude towards risk, it reflects the perception of risk and the deterioration of well -being staff (extra work, uncertainty) incurred during the creation. For some, this risk can be an element of entrepreneurial orientation, whereas for many others, there is a brake factor. This reflects exposures to behavioral and emotional risks which depend on both of its features and the perception developed in the literature. The 14 items express the will of the contractor to incur significant resources, seize opportunities, and also making the allocation of resources. The third factor related to pro-activity, it includes items of dynamic organizational behavior as a facet of assertiveness and a strategy of competition. Pro-activity is represented by six items to assess the competitive position of the contractor in relation to his competitors in order to achieve continuous monitoring of the environment, allow companies to generate competitive advantages.

Five explanatory variables may influence the absorption capacity. Indeed, in order to measure the relational network of the entrepreneur, we opted for five key variables namely: Scale of network, density of network, structural holes, nature of social ties and attribute of alters.

The values shown in the following two tables are those of the bootstrap (100 replications with identical size to that of the sample). The adjustment indices of are satisfactory. However, the results of the causal model indicate significant and positive statistical relationship with the absorption capacity (although the correlations are significant at the $5 \%$ and $10 \%$ ).

Table 2: Validation of the determinants of absorptive capacity using index

\begin{tabular}{|c|c|}
\hline Index & Value (ML function) \\
\hline AGFI & 0.94 \\
\hline GFI & 0.99 \\
\hline RFI & 0.87 \\
\hline TLI & 0.89 \\
\hline CFI & 0.95 \\
\hline RMSEA & $0.02[0.007 ; 0.041]$ \\
\hline
\end{tabular}

Table 3: Statistical and practical significance of the determinants of absorptive capacity

\begin{tabular}{|l|c|}
\hline \multicolumn{1}{|c|}{ Statistical significance } & $\begin{array}{c}\text { Practical } \\
\text { significance }\end{array}$ \\
\hline $\begin{array}{l}\text { Scale of network } \rightarrow \text { Absorption capacity } \\
\text { Correlation }: 0.218(\mathrm{t}=3.16)^{* * *} \\
\text { After Bootstrap }: 0.217(\mathrm{~s}=0.032)\end{array}$ & \\
& \\
Density of network $\rightarrow$ Absorption capacity & \\
Correlation $: 0.07(\mathrm{t}=1.18)^{* * *}$ & $\mathrm{R}^{2}=0.274$ \\
After Bootstrap $: 0.01(\mathrm{~s}=0.124)$ & After \\
& booststrap \\
Structural holes $\rightarrow$ Absorption capacity & $=0.289$ \\
Correlation $: 0.324(\mathrm{t}=3.24)^{* * *}$ & \\
After Bootstrap $: 0.284(\mathrm{~s}=0.034)$ & \\
& \\
\hline
\end{tabular}




\begin{tabular}{|l|l|}
\hline Nature of social ties $\rightarrow$ Absorption capacity & \\
Correlation $: 0.229(\mathrm{t}=5.12)^{* *}$ & \\
After Bootstrap $: 0.135(\mathrm{~s}=0.007)$ & \\
& \\
Attribute of alters $\rightarrow$ Absorption capacity & \\
Correlation $:-0.141(\mathrm{t}=3.28)$ & \\
After Bootstrap $: 0.101(\mathrm{~s}=0.004)$ & \\
\hline
\end{tabular}

Threshold of significance: $* * *(1 \%),{ }^{* *}(5 \%)$, no stars (not significant)

The table highlights the value and significance of the correlations between the components of relational network (Xi) and variable absorption capacity $\left(\mathrm{M}^{\prime}\right)$, the correlations between the $(\mathrm{Xi})$ and the variable entrepreneurial orientation $(\mathrm{Y})$ and finally, the correlations between $(\mathrm{X})$ and $(\mathrm{Y})$ when mediation $\left(\mathrm{M}^{\prime}\right)$ is controlled.

Table 4: Correlation between relational network components and the absorption capacity

\begin{tabular}{|c|c|c|c|}
\hline Relation & $\mathbf{X}_{\mathbf{i}} \rightarrow \mathrm{CA}$ & $\mathbf{X}_{\mathrm{i}} \rightarrow \mathrm{OE}$ & $X_{i} \rightarrow O E\left(M^{\prime}\right.$ controlled) \\
\hline $\begin{array}{l}\text { Density of network } \\
\qquad\left(\mathbf{X}_{1}\right)\end{array}$ & $\begin{array}{l}\text { Correlation : } 0.144 \quad(\mathrm{t}=1.77) \\
\text { Boostrap }: 0.122(\mathrm{~s}=0.024) \\
\mathrm{R}^{2}=0.08\end{array}$ & $\begin{array}{l}\text { Correlation : } 0.131 \quad(\mathrm{t}=1.66) \\
\text { Boostrap :0.112(s=0.041) } \\
\mathrm{R}^{2}=0.06\end{array}$ & $\begin{array}{l}\text { Correlation : } 0.0077(\mathrm{t}=0.45) \\
\text { Boostrap }: 0.008(\mathrm{~s}=0.66)\end{array}$ \\
\hline $\begin{array}{l}\text { Scale of network } \\
\qquad\left(\mathrm{X}_{2}\right)\end{array}$ & $\begin{array}{l}\text { Correlation : } 0.125 \quad(\mathrm{t}=1.89) \\
\text { Boostrap : } 0.122(\mathrm{~s}=0.018) \\
\mathrm{R}^{2}=0.036\end{array}$ & $\begin{array}{l}\text { Correlation :0.167 } \quad(\mathrm{t}=2.12) \\
\text { Boostrap :0.184(s=0.04) } \\
\mathrm{R}^{2}=0.09\end{array}$ & $\begin{array}{l}\text { Correlation }: 0.084 \quad(t=1.69) \\
\text { Boostrap }: 0.095(s=0.041)\end{array}$ \\
\hline $\begin{array}{l}\text { Structural holes } \\
\left(\mathrm{X}_{3}\right)\end{array}$ & $\begin{array}{l}\text { Correlation : } 0.244 \quad(\mathrm{t}=3.16) \\
\text { Boostrap :0.188( } \mathrm{s}=0.032) \\
\mathrm{R}^{2}=0.125\end{array}$ & $\begin{array}{l}\text { Correlation :0.149 }(\mathrm{t}=5.28) \\
\text { Boostrap :0.451( } \mathrm{s}=0.03) \\
\mathrm{R}^{2}=0.369\end{array}$ & $\begin{array}{l}\text { Correlation }: 0.053 \quad(\mathrm{t}=0.94) \\
\text { Boostrap }: 0.064(\mathrm{~s}=0.017)\end{array}$ \\
\hline $\begin{array}{l}\text { Nature of social } \\
\text { ties } \\
\left(\mathrm{X}_{4}\right)\end{array}$ & $\begin{array}{l}\text { Correlation : } 0.123 \quad(\mathrm{t}=2.17) \\
\text { Boostrap :0.144(s=0.028) } \\
\mathrm{R}^{2}=0.28\end{array}$ & $\begin{array}{l}\text { Correlation : } 0.354 \quad(\mathrm{t}=2.47) \\
\text { Boostrap :0.298( } \mathrm{s}=0.015) \\
\mathrm{R}^{2}=0.128\end{array}$ & $\begin{array}{l}\text { Correlation }: 0.144 \quad(\mathrm{t}=1.98) \\
\text { Boostrap }: 0.098(\mathrm{~s}=0.032)\end{array}$ \\
\hline $\begin{array}{l}\text { Attribute } \\
\text { of alters } \\
\left(\mathrm{X}_{5}\right)\end{array}$ & $\begin{array}{l}\text { Correlation : } 0.28 \quad(\mathrm{t}=2.08) \\
\text { Boostrap :0.301( } \mathrm{s}=0.04) \\
\mathrm{R}^{2}=0.32\end{array}$ & $\begin{array}{l}\text { Correlation : } 0.125(\mathrm{t}=2.12) \\
\text { Boostrap }: 0.128(\mathrm{~s}=0.018) \\
\mathrm{R}^{2}=0.08\end{array}$ & $\begin{array}{l}\text { Correlation : } 0.075(\mathrm{t}=1.68) \\
\text { Boostrap }: 0.065(\mathrm{~s}=0.032)\end{array}$ \\
\hline
\end{tabular}

Regarding the mediating effect of the absorption capacity (M), the results show that the relations between the $\mathrm{Xi}$ and absorption capacity are significant at the $1 \%$ level, and the relationship between $\mathrm{X}$ and $\mathrm{Y}$ when $\mathrm{M}$ is controlled are more significant than for the variables related to the density of the network and relational structural holes), but for the other structural components of the relationship network, correlations are lower when $\mathrm{M}$ is controlled.

This result is convergent with that of the study and Kelly Hayton, (2006), and pursuant rather to the organizational model proposed by Prieto.

If you want further explanations offered for this phenomenon, it may be noted, for example that according to Zahra and al., (1999) in rich countries where cultures are more 
individualistic, the absorption capacity takes the form of a learning process. At this level, absorption capacity increases the likelihood to achieve a better understanding of the mind.

\section{Concluding remarks}

This paper reveals an interesting result, the preponderant weight of the absorption capacity in predicting new business opportunities which are formulated by the entrepreneurial orientation. Indeed, the absorption capacity appears each time as a set of organizational routines which improve relationships in the supply chain.

Finally, we conclude the evidence of partial mediation in the relations between relational network and entrepreneurial orientation by the variable absorption capacity". This result confirms partly organizational modeling.

In this respect, in the specific case of SMEs, the absorption capacity is equated with a better interlocutor for an entrepreneur in order to strengthen and identify strong entrepreneurial orientation and, by leveraging its relationship network whether its mechanisms. This observation is all obvious that such companies do not have sufficient resources to choose them- selves their entrepreneurial orientation.

\section{References}

1. Aldrich, H. \& Zimmer, C. (1986). Entrepreneurship through social networks. In D. Sexton \& R. Smiler (eds.) .The Art and Science of Entrepreneurship, 3-23.

2. Baron, R. M. \& Kenny, D. A. (1986). The moderator-mediator variable distinction in social psychological research: Conceptual, strategic, and statistical considerations. Journal of Personality and Social Psychology, 51, 1173-1182.

3. Bogner, W. C. \& Barr, P. S. (2000). Making Sense in Hypercompetitive Environments: A Cognitive Explanation for the Persistence of High Velocity Competition. Organization Science, 11(2), 212-226.

4. Bojica, A.M. \& Fuentes Fuentes, M. M. (2011). Knowledge acquisition and corporate entrepreneurship: Insights from Spanish SMEs in the ICT sector. Journal of World Business, 47(3), 397-408. - Bower, G. H., \& Hilgard, E. R. (1981). Theories of learning (5th ed.). Englewood Cliffs, N.J.:Prentice-Hall.

5. Chorn, N.H. (1991).The alignment theory: creating strategic fit. Management Decision, 29, 20-24.

6. Cockbur, I.M. \& Henderson R. M. (1998). Absorptive capacities, co-authorship and organization of research in drug industry . Journal of Industrial Economics, vol. 46, $\mathrm{n}^{\circ}$ 2, 157-182.

7. Cohen, W. M. \& Levinthal, D. A. (1990). Absorptive capacity: A new perspective on learning and innovation. Administrative Science Quarterly, 35(1), 128-152.

8. Covin, J. G. \& Slevin,D. P. (1989). Strategic management of small firms in hostile and benign environments. Strategic Management Journal, 10, 75-87.

9. Daft, R. L. \& Weick, K. E. (1984). Toward a model of organizations as interpretation systems. Academy of Management Review, 9(2), 284-295.

10. Daghfous, A. (2004). Absorptive capacity and the implementation of knowledgeintensive best practices. S.A.M. Advanced Management Journal, 69(2), 21-27.

11. Dale, W. (1994). Learning Organizations in Managing Learning. London: Routledge

12. Danneels, E. (2002).The dynamics of product innovation and firm competences, Strategic Management Journal, 23, 1095-1121.

13. Fleming L.\& Sorenson, O. (2001). Technology as a complex adaptive system: evidence from patent data. Research Policy 30, 1019-1039.

14. Hart, S. (1992). An integrative framework for strategy-making processes. Academy of Management Review, 17, 327- 351. 
15. Hayton J.C. \& Kelley . D.J. (2006). A competency-based framework for promoting corporate entrepreneurship. Human Resource Management, vol. 45, n 3, p. 407-427.

16. Hult, G. T. M. Nichols, E. L. Jr. Giunipero, L. C. \& Hurley, R. F. (2000). Global organizational learning in the supply chain: A low versus high learning study. Journal of International Marketing, 8(3), 61-83.

17. Hurley, R. F. \& Hult, G. T. M. (1998). Innovation, market orientation, and organizational learning: An integration and empirical examination. Journal of Marketing, $62(3), 42-54$.

18. Julien, P. A. E. Andriambeloson. \& C. Ramangalahy (2004). Networks, weak signals and technological innovations among SMEs in the land-based transportation equipment sector . Entrepreneurship and Regional Development, vol. 16, no 4, 251-270.

19. Lane, P.J. Koka, B.R. \& Pathak, S. (2006). The reification of absorptive capacity: A critical review and rejuvenation of the construct. Academy of Management Review, 31(4), 833- 863.

20. Lane, P.J.Lubatkin, M. (1998). Relative absorptive capacity and interorganizational learning. Strategic Management Journal, 19: 461-477.

21. Lopez, S. P. Peon, J. M. \& Ordas, J. V. (2005). Organizational learning as a determining factor in business performance. The Learning Organization, 12(3), 227-245.

22. Lumpkin G. T. \& Dess, G. G., (1996) .Clarifying the Entrepreneurial Orientation Construct and Linking it to Performance. Academy of Management Review, 21, 135-172.

23. Miller, D, 1983. The correlates of entrepreneurship in three types of firms. Management Science 29, 770-91.

24. Mintzberg, H. (1973). Strategy making in three modes. California Management Review, 16(2) , 44-53.

25. Nath, D. \& Suharshan, D. (1994). Mesuring strategy coherence through patterns of strategic choices. Strategic Management Journal, 15, 43-61.

26. Nevis, E.C. Debila, A.J. \& Gould, J.M. (1995). Cited by Lopez, S.P. \& al. (2005). Organizational learning as a determining factor in business performance. The Learning Organization, 12(3), 227-245.

27. Oviatt, BM. \& McDougall, PP. (2005). Defining International Entrepreneurship and Modelling the Speed of Internationalization (pp. 537-554). Entrepreneurship Theory and Practice, Vol.29, No. 5

28. Prieto, I.M. (2010). Aportación de la gestión de recursos humanosa la capacidad ambidextra: Un análisis en Castilla y León. In:Internacionalización e innovación: Factores clave para el éxitoempresarial.

29. Schilling, M. A. (1998). Technological lockout: An integrative model of the economic and strategic factors driving technology success and failure (pp. 267-284). Academy of Management Review, Vol.23, No.2, ISSN 0363-7425.

30. Shane, S. \& Venktaraman, S. (2000). The Promise of Entrepreneurship as a Field of Research (pp . 217-226) .The Academy of Management Review, Vol. 25, Nº 1.

31. Shane, S. (2000). Prior Knowledge and the Discovery of Entrepreneurial Opportunities. Organization Science, 11, 4, 448-469.

32. Tarek, B. H. (2014). Lagged R\&D spillovers and international competitiveness: A sectoral approach in the case of Tunisia (pp. 31-41). Social Economic Debates, Vol. 3, No. 1.

33. Thomas J. Clark, S. \& Gioia, D. (1993). Strategic sensemaking and organizational performance: Linkages among scanning, interpretation, action, and outcomes (pp. 239-270). Academy of Management Journel, 26.

34. Todorova, G. \& B. Durisin. (2007). Absorptive capacity: valuing a reconceptualization.(pp. 774-786). Academy of Management Review, vol. 32, no 3, 
Vaghely, I.-P. P. A. Julien et A. Cyr . (2007). Information transformation: some missing links (pp. 157-172). Human Systems Management, vol. 26, no 2 .

35. Venkatraman, N. and Prescott, J. E. (1990). Environment-Strategy Coalignment: An Empirical Test of its Performance Implications. Strategic Management Journal. 11, 1-23.

36. Vinding, A. L. (2006). Absorptive capacity and innovative performance: A human capital approach ( pp. 507-517). Economics of Innovation \& New Technology, 15(4-5).

37. Voss, G. B., Sirdeshmukh, D. \& Voss, Z. G. (2008). The effects of slack resources and environmental threat on product exploration and exploitation. Academy of Management Journal,51(1), 147-164.

38. Wiklund, J. (1999) .The sustainability of the entrepreneurial orientationperformance Relationship (pp.37-48). Entrepreneurship Theory \& Practice, Vol. 24, $\mathrm{n}^{\circ} 1$.

39. Wiklund, J. \& Shepherd, D. (2003). Knowledge-based resources, entrepreneurial orientation, and the performance of small and medium sized businesses. Strategic Management Journal, 24, 1307-1314.

40. Zahra S.A. \& Covin J.G., (1995). Contextual Influences On The Corporate Entrepreneurship- Performance Relationship: A Longitudinal Analysis. Journal of Business Venturing, vol. 10, p. 43-58.

41. Zahra, S. A. and George, G. (2002). Absorptive capacity: A review, reconcepualisation, andextension. Academy of Management Review, 27(2) ,185-203.

42. Zahra, S.A., A.P. Nielsen \& W.C. Bogner. (1999b) .Corporate entrepreneurship, knowledge, and competence development. Entrepreneurship: Theory \& Practice, 23(3), 169-189.

43. Zahra, S.A. D.F. Jennings \& D.F. Kuratko. (1999a) .The antecedents and consequences of firm-level entrepreneurship: The state of the field. Entrepreneurship: Theory \& Practice, 24(2), 47-67.

44. Zeleny, M. (2005). Human Systems Management: Integrating Knowledge, Management and Systems, World Scientific Publishers.

45. Zollo, M, Winter, SG. (2002). Deliberate learning and the evolution of dynamic capabilities. Organization Science 13, 339-351. 